\title{
JOURNAL OF PROCEEDINGS.
}

\author{
December $4 t h, 1837$. \\ J. F. Stephens, Esq., President, in the Chair.
}

Donations.

Bulletin de la Société Impériale des Naturalistes de Moscou. 1837. No. IV. And

Réglement de la Société Imp. Nat. de Moscou. Both presented by that Society.

Der Naturforscher. 27 vols. 8vo. Presented by the Rev. F. W. Hope.

Genera et Species Curculionidum. Tom. IV. Pars I. By the Author, C. J. Schönherr, For. Hon. M.E.S.

The A thenæum for November. By the Editor.

G. F. Shipster, Esq. was elected an Ordinary Member of the Society.

$$
\text { Memoins, Exhibitions, \&c. }
$$

Mr. F. Smith exhibited a specimen of Halictus nitidiusculus $q$, in the abdomen of which two Strepsipterous insects were inclosed.

Mr. Westwood gave some account of the three following memoirs by Professor Wesmael of Brussels recently published.

1. On a hermaphrodite Ichneumon, in which the anterior part of the body is female and the posterior male.

2. On a hermaphrodite Argynnis Paphia, in which the right side is male and the left female.

3. On a deformed individual of Nymphalis populi, captured near Brussels, which still retained the head-case of the larva inclosing the head-case of the pupa, as well as the head of the imago, in an immature state of developement. vor. II. 
Mr. Westwood also mentioned that a monstrosity similar to the latter case was described in Der Naturforscher, observed in a specimen of Cerura vinula; and contended that the observation of M. Wesmael absolutely proved that the head of the imago was contained within the head of the larva, and did not occupy two segments as asserted by Dr. Ratzeburg and Mr. Shuckard, this opinion being still maintained by the latter. Mr. Newman stated that immediately previous to moulting the head of the enclosed larva was to be found beneath the first segment of the body, and entirely disengaged from within the head of the still enveloping skin. Mr. Westwood contended that this was not to be considered as a proof that the head of the enclosed larva occupied the head and anterior segment of the old skin, but that it was the necessary result of the disengagement of the enclosed larva from its surrounding membrane, and of the endeavours used by the enclosed larva to effect a passage by its head through a fissure down the back. Mr. Shuckard, on the other hand, considered it not impossible that the membranous covering of the first segment of the larva in M. Wesmael's specimens might have shrivelled up, leaving the head of the butterfly enclosed in the head of the larva alone, and not in the head and first segment, as it ought to do according to the theory of Dr. Ratzeburg.

Mr. Westwood also gave an account of the Canon Schmidberger's observations on Psilus Boscii, contained in Kollar's work on insects obnoxious to vegetation recently published, [and included in Miss Loudon's Translation of that work published subsequently.]

The following Memoir was read:-

"Observations respecting various Insects which have at different Times afforded Food to Man." By the Rev. F. W. Hope.

January 1 st, 1898.

J. F. Stephens, Esq., President, in the Chair.

Donations.

On the Temperature of Insects. Parts I. and II. (From the Philosophical Transactions.) By George Newport, Esq., the author thereof. 
Magazine of Natural History. New Series. No. 12. By the Editor.

The A thenæum for December. By the Editor.

The Entomological Magazine. No. 21. By the Editor.

The Naturalist for November and December, 1837. By the Editor.

Edward Charlesworth, Esq., F.G.S., of Leicester Square; and T. W. Maltby Esq., of Turnham Green, were elected Ordinary Members of the Society.

\section{Memoirs, Exhibitions, \&c.}

Mr. Hanson exhibited a large collection of North American insects collected by Messrs. Doubleday and Forster.

Mr. Hope exhibited a portion of a splendid collection of insects collected by Colonel Whithill in the Concan and Ceylon.

Mr. Raddon exhibited a quantity of Cayenne pepper, in which a number of specimens of Anobium paniceum had been reared. Likewise some portions of the external parts of insects found imbedded in peat at the depth of fifty feet in digging the foundation of a bridge at Bristol.

Mr. Shipster exhibited the nest of a trap-door spider from Southern Australia, in which the door, instead of being circular as in $C t$. nidulans, was semicircular and attached by a transverse section on one side.

Mr. Spence communicated an extract from a provincial paper, giving an account of an advantageous mode of getting rid of the wire-worm in its attacks on turnips by employing boys to collect the worms at the price of $2 d$. or $1 \frac{1}{2} d$. per 100 , by which means the number of 18,000 had been collected in one field, which at the former price would cost $1 l .2 s .6 d$., a sum well expended by saving an acre of turnips worth from $5 l$. to $7 l$. As many as fifty worms had been found in a single root. Mr. Hope also stated that he had found the larvæ of one of the Elateride abundant in turnips, and also that the common earwig had during the past autumn abounded to an extraordinary degree in various parts of England. At Cheltenham Forficula borcalis had appeared in countless myriads, and by far the greatest number of specimens which he had examined were infested with Filaria, three or four being often found in one individual.

Mr. Stephens also stated that he had found the earwig extremely abundant at Camberwell, whilst Messrs. Ingpen and 
Westwood had noticed but very few specimens at Chelsea and Hammersmith.

The following Memoirs were read:-

"Observations on the Use of the Antennæ of Insects." By George Newport, Esq.

"Description of a Hybrid Smerinthus, with Remarks on Hybridism." By J. O. Westwood, F.L.S.

Mr. Hope, in allusion to the latter of these papers, stated that it was a well-known fact that the offspring between the setter and pointer, allowed only to breed inter se, would in the course of three generations exhibit indications of a tendency towards the characters of the male parent. Mr. Yarrell also stated that in those hybrid fowls which he had examined he had found the male organs to be in excess, and the reverse to be the case with the female parts, the ovaries being very slightly developed. He also stated that it was a common practice amongst the breeders of cage birds, resulting from such excess of the male organs, to make use of one of these rank mules to bring forward slow hens, which would not pair, but which, when excited by the presence of the mule bird, was brought into the presence of the male bird. He had known the bullfinch cross with the canary, which were the most widely apart of any birds hitherto known to produce hybrids.

Anniversary Mceting, January 22nd, 1838.

J. F. Stephens, Esq., President, in the Chair.

In pursuance of the By-laws, the four following gentlemen were removed from the Council :

W. S. Mac Leay, Esq. Samuel Hanson, Esq.

W. W. SAunders, Esq. W. Sells, Esq.

and the four following gentleman elected in their stead:

R. J. Ashton, Esq. $\quad$ F. W Alker, Esq.

J. S. Bowerbank, Esq. C. Darwin, Esq.

And the following gentlemen were elected officers for the ensuing year :

President ........ J. F. Stephens, Esq.

Treasurer........ W. Y. YRRELL, Esq.

Secretary ......... J. O. Westwood.

Curators ....... Messrs. Shuckard and Westwood. 
Mr. Yarrell, on behalf of the auditors of the treasurer's accounts, read an abstract thereof, and made a verbal communication concerning the prosperous state of the affairs of the Society.

J. F. Stephens, Esq., the President, then read an address upon the state of the Society, its views, progress, and prospects.

It was resolved that a vote of thanks should be given to the President for his address, and that he should be requested to allow the same to be printed for distribution amongst the members.

It was announced that two prize essays upon Athalia centifolice had been received, and that they had been submitted to a committee to examine and report on their respective merits.

February 5th, 1838.

J. F. Stephens, Esq., President, in the Chair.

\section{Donations.}

The Coleopterist's Manual. Part I. By the Rev. F. W. Hope. Catalogue of the Hemipterous Insects contained in the Collection of the Rev. F. W. Hope. Both presented by the Rev. F. W. Hope.

Genera et Species Curculionidum. Tom. IV. Pars II. By C. J. Schönherr, For. Hon. M. E. S.

The Athenæum for January. By the Editor.

The Magazine of Natural History for February. By the Editor.

No. 22 of the Entomological Magazine. By E. Newman, Esq. Sixty-one Species of minute British Hymenoptera. By F. Walker Esq.

William Frederick Evans, Esq., of the Admiralty, and of Elm Place, Brompton, was elected an Ordinary M. E. S.; and

M. Louis Agassiz, of Neufchâtel, an Ordinary Foreign M.E.S.

The President nominated the following gentlemen to act as Vice-Presidents during the ensuing year :

The Rev. F. W. Hope.

W. E. Shuckard, Esq.

J. G. Children, Esq.

C. Darwin, Esq. 


\section{Exhibitions, Memoirs, \&c.}

Mr. Shipster exhibited a large collection of Coleopterous insects obtained by him from the rough turpentine.

Mr. Hope exhibited a selection from a collection of insects made by E. T. Downes, Esq., Assistant Surgeon at Neemuck in the East Indies, including a new Paussideous insect (Platyrhopalus angustus, Westw.), a Dipterous insect closely allied to Sphryrocephala (Say), a large species of Cermatia, a Solpuga, a Pimelia, a very large Onitis, Oiceoptoma tetraspilota, \&c. Alluding to the last-mentioned insect, Mr. Hope opposed the opinion that Necrophagous insects were of great rarity in India, believing their apparent rarity to have originated in the prejudices entertained by the native castes against touching dead bodies. He moreover considered, from the exhibition now made, that there must be a considerable agreement between tropical Asia and Africa.

The Rev. L. Jenyns exhibited an apod larva, of which three individuals had been found during the preceding summer in the key-hole of a writing-desk, embedded in a mass of clay, without any food having been apparently laid up in store.

The completion of Mr. Newport's Memoir on the Use of the Antennæ was read; in support of the observations in which, Mr. Hope entered into various remarks upon the different senses, considering that there was an intimate connexion between sight and hearing (the one being requisite to obtain clear perceptions of the objects causing impressions upon the organs of the other sense), and which seemed to be proved, amongst the Longicorn beetles, by the antennæ being inserted in a deep notch of the eye. He was hence induced to consider that the sense of hearing existed in insects either in the terminal or basal joint of the antennæ. The ordinarily minute size of the second joint seemed to him as likely to have for its object the condensing of the sound carried along the nerves of the elongated terminal joints, and which afterwards diverged in the large basal joint.

Mr. Newport stated that he had recently, at the request of Mr. Hope, made some anatomical observations upon the internal parts of the head in the region of the base of the antennæ, and that he had discovered the two membranes of which Treviranus had spoken. At the base of the antennæ in Blatta he had discovered a free space, inclosing a membrane over which passed a branch of the nerve from the base of the antennary nerve, without the intervention of a sac. 
Mr. Westwood, in reference to some observations made by Mr. Newport on the excitement previous to impregnation of a species of Pleromalus by the contact of the antennæ of the opposite sexes, stated that he had observed the latter operation in other species of that family, and that the act of impregnation itself occurred in the ordinary manner, the vagina of the female being situated near the base of the abdomen beneath. He likewise considered that the proceedings of the house-fly, so often observed in autumn, did not constitute copulation, but were merely acts of excitement.

March 5th, 1838.

J. F. Stephens, Esq., President, in the Chair.

Donations.

Proceedings of the Zoological Society, from January to September, 1837. By that Society.

Annales de la Société Entomologique de France. 1837. Livr. 3. Presented by that Society.

Bulletin de la Société Imper. des Naturalists de Moscou. 1837. Part 5. By that Society.

The Magazine of Natural History. No. 1j. By the Editor.

Description of new Species of Coleoptera. By M. Zoubkoff.

Letter to his Royal Highness the Duke of Sussex. By Mr. Donaldson.

The Athenæum for March. By the Editor.

The Annals of Natural History. No. I. By the Editors.

\section{Exhibitions, Memoirs, \&c.}

Mr. Raddon exhibited a portion of gum containing insects which he considered to be gum Copal, and another portion without insects which he named Animè ; and made some observations on the distinction between these two substances. Mr. Hope, however, considered that both portions of gum were Anime, retaining his opinion that the Copal never contained insects. There was great difficulty in tracing the original country of these gums, the dealers mixing them promiscuously, but he believed that the gum produced in the Old World was insectiferous, whilst that exuding from trees in the New World was not. There was also great difference between the same gim at different times, that which was a year old being much paler than that which was four years old. 
Mr. Hope also stated that he had prepared several outline maps, with a view to facilitate the knowledge of Entomological Geography, and requested the assistance of members in filling up the outlines.

Mr. Raddon stated, upon the authority of a friend, that the noise produced by Acherontia atropos is occasionally made whilst the insect remained in the pupa state, immediately before bursting forth, and stated his opinion that the sound proceeded from the head.

Mr. Saunders exhibited a beautiful specimen of Urania Rhipheus, captured on board a vessel in the Mozambique Channel many leagues from land.

Mr. Bainbridge exhibited three Coleopterous and two Lepidopterous insects which had been greatly infected with grease, but which had been cleansed by immersion in petroleum, the colours of the Lepidoptera not appearing to be affected by the process. Mr. Shuckard stated that this remedy had been long previously suggested by Treitschke.

The following Memoirs were read :-

"Description of a new Strepsipterous Insect from South America." By Robert Templeton, Esq., R.A.

" Notes upon the Staphylinida." By Fred. Holme, Esq.

" Description of Platyrhopalus angustus." By J. O. Westwood.

$$
\text { April 2nd, } 1838 .
$$

J. F. Stephens, Esq., President, in the Chair.

\section{Donations.}

Notices sur les Ravages causés par la Pyrale de la Vigne.

Considerations nouvelles sur les Dégats occasionnés par la Pyrale de la Vigne.

Recherches Anatomiques et Physiologiques sur la Maladie contagieuse qui attaque les Vers à Soie.

Nouvelles Expériences sur la Maladie contagieuse qui attaque les Vers à Soie. All presented by M. V. Audouin, Foreign Hon. M. E. S., the Author thereof.

Entomologische Beitrage, von C. H. G. von Heyden. Presented by the Author. 
The Magazine of Natural History. No. 16. By the Editor.

Observations made by order of the Meteorological Society. By that Society.

Mr. Henry G. Bohn, of York Street, Convent Garden, was elected an Ordinary Member of the Society; and

M. Sahlberg, of Finland, an Ordinary Foreign Mensber.

\section{Eximbitions, Memoirs, \&c.}

Mr. Bainbridge exhibited a monstrous Clivina fossor, in which the right antenna was furcate and considerably incrassated.

Mr. Shipster exlibited a preparation of the human eye in spirits, to which a specimen of Latridus porcatus was attached, and which it was considered had become accidentally attached during the process of preparation.

Mr. Barker, M.E.S., informed the meeting that the minute house-ant had been observed to be driven away by washing the places it frequented with water in which the outer green skins of walnuts had been soaked.

Mr. Westwood, in alluding to Mr. Templeton's discovery of a Strepsipterous insect in the body of one of the Brazilian Sphegidee described at the last meeting of the Society, stated the discovery of two chrysalides of another species of the same order, in the abdominal cavity of Ammophila sabulosa, recorded by M. Léon Dufour (Ann. Sci. Nat., January, 1837); and Mr. Hope stated that he had found at Southend specimens of the same sand-wasp having the abdomen swollen, and which he had attributed to some disease, but which he was convinced was produced by the presence of Strepsiptera.

Mr. Westwood also noticed the observation of M. Dufour in the memoir above alluded to, in which a parasite larva found in the interior of the body of Andrena aterrima was observed to have one of its extremities attached to one of the great trachean vesicles of the bee by two of the trachean tubes arising therefrom which penetrate into the body of the parasite, and which afforded some confirmation of the observations made by him on the connexion of the pupa of the Stylops with the bee described by him in these Transactions (vol. i. p. 170).

Mr. Westwood also noticed, in connexion with Mr. Spence's observations made at a previous meeting upon the minute parasites found upon the outside of the pupæ of Scolylus destructor, that M. L. Dufour had discovered numerous minute worms in the 
viscera of the imago of Tomicus typographus like Vibrio, described by him in his Récherches Anatomiques sur les Coléoptéres.

The Memoirs read were-

"Monograph on the Genus Holoptilus. By J. O. Westwood, F.L.S.

The conclusion of Mr. Hope's Memoir on Edible Insects.

" Facts proving that the best remedy for clearing turnip-fields is found in the use of poultry for that purpose." By W. Sells, Esq. In a previous communication made to the Society on the 3rd October, 1836, Mr. Sells stated that at Compton, in Surrey, a turnip-field, of eight and a half acres, was, in the preceding year, completely demolished by Athalia centifolia. A thunder-storm, accompanied by heavy rain, destroyed myriads of them, so that, as it was described to him, basketsful might have been swept up on following morning. The country people called them the black army, and said they had not been seen there for twenty-five years before. Mr. Sells then mentioned the occurrence of the negro caterpillar at Long Ditton, Ham, and near Guildford, where its ravages had been equally severe.

Mr. Sells then proceeded to state: “ On Sept. 26th I examined some turnip-fields near Kingston, and found them suffering from the negro caterpillar, though comparatively in a slight degree at present. Having taken a boy of about ten years old with me, I desired him to pick them off the leaves, and timed him by my watch, in order to ascertain the number he collected in a given time. I found that he gathered them at the rate of 180 in an hour, which being followed up for eight hours only a day, would give about 1500 , or 9000 a week ; so that ten or a dozen children, of from six to ten years old, under the superintendence of a man, would collect, even where they are relatively few, as many as $90,000$ or $] 00,000$ a week. I proposed this plan to the farmer who rents the land, and he has promised me to act upon it immediately. I recommended his paying the children so much for a given measure of the caterpillar, as at the rate of $6 d$. a pint, and the man 2s. a day." Mr. Sells then observed upon the little benefit to be derived from the use of tobacco water, quick lime, or soot; brushing the caterpillars off the plants with brushes drawn over the fields, with ropes, or ploughing up the parts of the field where they first appear in order to prevent their further progress. He further observed that where they are numerous they might be brushed off into little pans or shovels formed somewhat like a heart, but with a deeper notch in front so as to allow them to be 
pushed under the leaves of the plant, as on the least disturbance they coil up and roll off.

"If ducks and poultry could be induced to eat these caterpillars, it would be a cheap, convenient, and expeditious mode of removing them. In America, turkeys are turned into the tobacco plantations to pick off the larvæ of a Splinx, which would otherwise devastate them; and in the West Indies the large cockroaches with spiny legs are a bonne bouche for the fowls, as in provision stores numbers of them are often found in empty flour barrels, when it is the practice to call the fowls and shake the cockroaches out of the barrel or box upon the ground, when they are greedily eaten by the poultry. If ducks and fowls were made to fast a few hours to quicken their appetite, they would very likely eat a quantity of these larvæ, given either alone or mixed with barley, and might thus by a little management be brought to first feed upon them and then to seek them in the fields."

In the present communication Mr. Sells states: "In the early part of last summer I took every opportunity of urging strongly upon the farmers, in the neighbourhood of Kingston and elsewhere, their making a fair trial of this best (beyond all question) of the remedies that have been devised for the extirpation of their enemy. I have now received the particulars of several instances wherein the use of poultry has been perfectly successful and they are as follows.

"Mr. W. M., a very intelligent farmer, at Elston, Bedfordshire, wrote last July: "In the summer of $1835 \mathrm{I}$ had twenty-four acres of English turnips quite destroyed. In $1830 \mathrm{I}$ had near seventy acres of Swedes, all of which were more or less infested; on the English this year not one was seen. Their work of destruction seemed to be facilitated by новING, for after that operation they increased a thousandfold. I then thought of the ducks and procured 160 young ones (old ones will not work), and kept them on the worst parts. They soon put a stop to the caterpillars; it was quite amusing to see how fast they would destroy them. The ducks were brought home and put into a barn, and fed with a little barley at night, or I should have lost all my friends, as their new food did not agree with them. My loss of turnips in 1835 only could not be less than $£ 100$.'

"Mr. P., at the Robin Hood farm, had his turnip fields last year invaded by the black army (as they have been called in Devonshire). He procured eighty ducks at Leadenhall Market, and turned them out. The first day they did not take kindly to their business, but on the following they went to work in good 
earnest and quickly accomplished their allotted task. That the ducks throve upon their new food, I had a positive proof in a fine couple of them which were obligingly sent me.

"Capt. W., of Long Dutton, also reports favourably of his obligations to the ducks; adding that turkeys would not touch the caterpillar, but that fowls were equally useful with the former.

"At Chertsey last year two adjoining farms were visited by the blacks. The farmer upon one of them put 150 fowls, most of them about half grown, into a waggon, which was drawn into the middle of his turnip-field, where they were turned loose, and quickly annihilated the caterpillars. His neighbour, Mr. L., the owner of the other farm, hearing of this fact, sent to borrow the fowls; they were immediately lent, and promptly rendered the same important service to him which they had done for their owner.

"The above particulars afford satisfactory proofs of the great advantages of using poultry, as the most certain, direct and complete means of destroying the black caterpillar; while all the other remedies which have been proposed, as sweeping with a rope, hand-picking, sprinkling quick lime, watering the fields with salt water, $\&$ c. are comparatively merely palliative, partial and imperfect in their operation, and not to be relied on. There is one point I would recommend to the attention of the farmerthat he should carefully preserve some of his expert, practised hunters of one year, in order that they may (if unluckily required) render him similar services in a subsequent one; and with this further advantage, that they would, by their example, induce the younger birds to commence their operations without loss of time. It is evidently of great consequence that the first appearance of the caterpillars should be carefully watched, and not be allowed to pass unregarded; but that, as soon as they are discovered, a number of young ducks or fowls, or both, should forthwith be set to work.

"What effect the intense cold experienced in January last may have upon the future appearance of Athalia centifolice must at present be problematical, but when we recollect that it remains in state of larva, enclosed in a slightly organized cocoon, at no great depth in the ground, through the winter, and that, moreover, there was no covering of snow upon the earth during the extreme severity of the weather, it may reasonably be expected that the numbers of this destructive insect will be very considerably reduced for some years to come." [See also the observations of Messrs. Sells and Manning, ante, p. lxiv.] 
Dr. Blundell stated, in connexion with Mr. Sells's remarks, that he had observed that in the southern states of North America as well as in England the partridges which feed upon a large ant are better flavoured than the ordinary ones. Mr. Sells also added that poultry are fed in the West Indies upon the larvæ of ants or white ants, men being regularly employed to collect the nests of those insects in the woods and bring them home.

Mr. Sells also stated that the larvæ of Prionus damicornis are eaten both by the blacks and creoles in the West Indies.

May 7 th, 1838.

J. F. Stephens, Esq., President, in the Chair.

\section{Donations.}

Proceedings of the Berwickshire Naturalists Club for 1837 . Presented by the Club.

No. 17 of the Magazine of Natural History. By the Editor.

Fabricii Entomologia Systematica. 2 vols. Presented by the Rev. F. W. Hope.

Nos. 23 and 24 of the Entomological Magazine. By the Editors.

The Athenæum for April. By the Editor.

No. 1 of an Introduction to the Modern Classification of Insects. By J. O. Westwood, the Author thereof.

Charles Thurston Thompson, Esq., of Bedford Place, Kensington; and

J. W. Horsley, Esq., of Turnham Green, were elected Ordinary Members of the Society.

Memoirs, Exhibitions, \&c.

Mr. Sells exhibited specimens of Copris lunaris and of the cocoon in which they pass the pupa state, and which appeared entirely to consist of vegetable matter.

Mr. Evans exhibited a specimen, accompanied by a figure, of Notonecta glauca, to the hind tibiæ of which were attached certain oval masses resembling eggs, and which were considered to be the ova of one of the water mites described as a distinct animal under the generic name of Achlysia. 
Mr. Ashton exhibited a collection of specimens of insects of various orders in spirits from Barbadoes.

The Rev. George May presented a piece of pear-tree bored to the centre by the larva of Zeuzera Esculi.

Mr. C. Curtis exhibited a domestic fly attacked by a great number of small Acari, which had attached themselves to the extremity of the body around the anus.

Mr. Yarrell exhibited a number of the larvæ of one of the Longicorn beetles which had been discovered by Mr. Leadbetter in a case of stuffed birds, where they were found to have so extensively burrowed into the branches upon which the birds were fixed as to render it necessary to remove them. The case had been closed for the last seven years, so that the insects must have remained so long in the egg or larva state.

Mr. Aldous presented a plain and coloured highly magnified figure of the head of the flea recently published by him, exhibiting the various parts of the mouth as they appear in the solar microscope.

Mr. Ingpen communicated the following notes upon the economy of Brachinus crepitans, and Sirex duplex:-

"Brachinus crepitans has been taken in immense profusion by Mr. Shipman on a bank in the Duke of Somerset's Park at Wimbledon, in the last week in April. On pulling down a part of the bank the ground was literally black with them, but on visiting the same spot a week afterwards a few only were found, and those by twos or threes under stones in the vicinity. What could be the cause of their congregating together in such a mass? Had they but just arrived at their perfect state? If so, the larvæ must be gregarious. The specimens, however, were perfectly mature. On killing some of the specimens in scalding water, one of them struck him in the face with its fundamental artillery at the distance of fifteen inches, at which times the abdomens of the females were distended to double their ordinary size.

"Several specimens of Sirex duplex were taken in the house of Mr. Edwards, at Henlow, Beds. The house had been built about three years when the family were very much alarmed by the appearance of these insects, at first few in number, but subsequently ' by thousands.' Innumerable holes in the floors of the rooms were made by the insects large enough to admit a small pencil case. There could be no doubt of their having been imported in the timber (which is supposed to have come from Canada), and therefore they must have been considerably more than three years in arriving at their perfect state." 
The following observations by Mr. Sells on the perforations of the larvæ of Sirex juvencus, were omitted in the Journal of Proceedings of the 1st of February, 1836, and are here introduced in connexion with Mr. Ingpen's remarks on Sirex duplex:-

"In tracing the mining operations of the larva of Sirex jurencus in the small sample of the wood submitted to my examination, they appear to be mainly carried on in a zig-zag manner; the insect proceeding either in a straight course with the fibre of the wood, diagonally, or tortuously, according to the texture it has to deal with, to the extent of an inch and half or two inches; it then eats its way transversely, and that very wisely only for a space just sufficient to allow of its turning round, when it advances about the same distance as at first, turns again and so on.

"The firmly compacted substance which completely fills the cylindrical passages formed by the insect, I apprehend to be its excrementitious rejectamenta; it is almost entirely composed of fine wood powder, is quite uncoloured by the secretions of the larva, and can admit but a very small supply of air for respiratory purposes.

"The pieces of wood which I have seen have all the perforations of the same size, as though formed by insects of the same bulk.

"Messrs. Kirby and Spence, when speaking of the indirect injuries caused by insects, confine their remarks on this subject to saying-Mr. Stephens informs me that the fir-trees in a plantation of Mr. Foljambe's in Yorkshire, were destroyed by Sirex gigas, while those of another belonging to the same gentleman in Wiltshire met with a similar fate from Sirex juvencus.' Now as it is always desirable to unite the utile with the dulce in scientific inquiries, and we should grant fair attention to the popular question of cui bono in these matters, it is worth while to inquire into and endeavour to trace out the whole history of this mischievous borer; and first, of the places and seasons wherein the female Sirex deposits her eggs, as it is probably in that state only that the enemy would be practically assailable, and its course of destruction be arrested.

"It occurs to me that the young larvæ may feed upon the alburnum, or soft parenchymatous parts of the inner bark, and thus in fact do more injury to the tree as regards its vitality than when it afterwards operates upon its solid internal parts. Upon these subjects it is not unlikely that some members of the Society may afford satisfactory information."

Mr. Westwood, in reference to the remark made by him at the 
meeting of the 2nd October, 1837, reported in p. lxvi., ante, and in the Entomological Magazine, No. 22, p. 185, on the analogy which might be supposed to exist between the food of the larvæ of the QEstrus equi and bovis, observed that Mr. Clark had noticed this analogy in his Memoir on the Bots (p. 22), although he had stated further that the food of the bot was nost probably the chyle or chyme. Mr. Sells defended his former opinion, which Mr. B. Clark had opposed in the Entomological Magazine, No. 24, adding that the bots were not found in that portion of the stomach in which the chyle or chyme was secreted.

The Rev. F. W. Hope communicated the following lists of the genera and species of insects infested by Filarice, with the names of the persons by whom observed, and other memoranda relative to the occurrence of the same.

\section{Coleoptera.}

1. Cychrus rostratus, Rev. F. W. Hope; taken at Netley, Salop.

2. Carabus morbillosus, Rev. F. W. Hope; three cases. nemoralis, J. F. Stephens, Esq., Middlesex, \& c. violaceus, Messrs. Stephens, Henslow and Hope;

Cambridge and Shropshire. catenulatus, J. F. Stephens, Esq., Middlesex, \&c. monilis, J. F. Stephens, Esq,, Middlesex, \&c.

3. Abax striola, Messrs. Stephens and Hope, Essex and Middlesex.

4. Steropus madidus, Messrs. Holme, Stephens and Hope; Oxfordshire, Middlesex, and Netley; of frequent occurrence.

5. Sphodrus leucopthalmus, Messrs. Stephens and Hope; in cellars, London and Middlesex.

6. Pristonychus terricola, F. W. Hope ; Southend, Essex, 1832, and Middlesex, 1836.

7. Pacilus cupreus, J. F. Stephens, Esq., Middlesex.

8. Calathus Stephensii, F. W. Hope, Berkeley, Gloucestershire.

9. Harpalus aneus, J. F. Stephens, Esq., Middlesex. ruficornis, J. F. Stephens, Esq., Middlesex.

binotatus, J. F. Stephens, Esq., Middlesex.

10. Pelorus blapoides, Rudolphi, Prussia?

11. Acilius sulcatus, F. W. Hope, Netley, Salop.

12. Colymbetes ferrugineus, F. W. Hope, Netley, Salop.

13. Necrophorus vespillo, F. W. Hope, Netley, Salop.

14. Silpha obscura, Rudolphi, Prussia?

15. Buprestis (species unknown), Rudolphi, Prussia? 
16. Blaps mortisaga, Messrs. Stephens, Jenyns, Hope and Rudolphi (see also Baker on the Microscope), Middlesex, Southend, and Prussia.

17. Adimonia alni, Rudolphi, Prussia?

18. Galleruca tanaceti, Rudolphi and F. W. Hope, Netley, 1836.

2. Dermaptera.

Forficula auricularia, J. $O$. Westwood, observed in dissection. auricularia, Messrs. Babington, Riley, Rudolphi and Hope ; Bristol, many instances; Prussia? and Netley. (species unknown), Léon Dufour in his Mem. sur les Labidoures.

\section{Orthoptera.}

1. Locusta hemitogia, Rudolphi, Prussia. verrucivora, Rudolphi, Prussia. viridissima, Messrs. Rudolphi and Stephens, Prussia and Middlesex?

2. Gryllus (species unknown), F. Holme, Esq., in the Ashmolean Museum.

\section{Neuroptera.}

Phryanea (species unknown), Rudolphi, Prussia.

(species unknown), F. W. Hope; many species are infested.

(species unknown), F. W. Hope ; eleven specimens in one insect, in Oct. 1836, Netley.

\section{Hemiptera.}

1. Cercopis spumaria, Rudolphi, Prussia.

2. Coccus (species unknown), J. O. Westwood, in my Cabinet.

\section{Hymenoptera.}

1. Tenthredo, larvæ of, Rudolphi, Prussia.

2. Bombus (species unknown), - Owen, Esq., in the College of Surgeons. terrestris, Rudolphi, in Prussia.

7. Diptera.

Chironomus plumosus, Rev. L. Jenyns, Cambridge? vOL. II. 


\section{Papilionidis.}

\section{Lepidoptera.}

Vanessa polychloros, Messrs. Stephens and Rudolphi, Middlesex. urtica, Rudolphi and F. W. Hope, Salop and Prussia. antiopa, Rudolphi, Prussia.

SPHINGIDE.

1. Smerinthus tilice, F. W. Hope, Sussex.

2. Deilephila euphorbia, Rudolphi, in the larva.

3. Hepialus humuli, F. W. Hope, in his Cabinet.

4. Notodonta ziczac, Rudolphi, Prussia.

5. Lasiocampa quercus, Rudolphi, Prussia. trifolii, Rudolphi, Prussia.

6. Leucoma salicis, Rudolphi, infested by Filaria.

7. Bombyx alni, Rudolphi, infested by Filaria.

8. Arctia caia, Rudolphi and F. W. Hope, Prussia and Essex.

9. Catocala nupta, Rudolphi, by Fil. acuminata.

10. Ennomos cratagata, J. F. Stephens, Esq., Middlesex.

11. Pyralis pomana, Rudolphi, Prussia.

12. Yponomeuta padella, Rudolphi, by $\boldsymbol{F}$. truncata.

The commencement of a monograph on the Coleopterous genus Popillia, by Edward Newman, Esq., F.L.S., was read. 